\title{
The Younger Dryas age of the Salpausselkä moraines in Finland
}

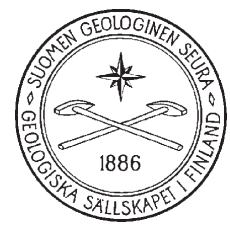

\author{
JOAKIM DONNER \\ Pohjoisranta 12 A 1, Fi-00170, Helsinki, Finland
}

\begin{abstract}
The late-glacial Younger Dryas Stadial, as defined over seventy years ago in Denmark, was compared with the withdrawal of the Scandinavian ice sheet and correlated in Finland in 1951 with the formation of the Salpausselkä moraines. Since then a great number of studies of Younger Dryas has eventually led to its definition in the Event Stratigraphy for the North Atlantic region, based on the oxygen isotope stratigraphy in the Greenland ice-core NGRIP. The age of the Younger Dryas / Preboreal boundary, the beginning of the Holocene, is in this stratigraphy dated at $11653 \mathrm{yr}$. BP, an age close to the age deter-mined for the drainage of the Baltic Ice Lake and the beginning of the rapid retreat of the ice margin from Salpausselkä II in Finland and the corresponding Billingen moraine in Sweden. This leads to the conclusion that the Salpausselkä moraines Ss I and Ss II were formed during Younger Dryas, according to the revised varve chronology between c. 12260 and c. 11600 yr. BP. The third Salpausselkä, Ss III, was according to this dating formed in early Holocene.

After the 1950s, when the Salpausselkä moraines were dated as having been formed during the Younger Dryas Stadial, the ages of the boundaries of Younger Dryas changed as a result of revisions of the time scales of varved clays and the use of radiocarbon ages and their calibrations. As a result of these changes the age of the two main Salpausselkä moraines, Ss I and Ss II, is older than assumed 60 years ago on the basis of the varve chronology.
\end{abstract}

Keywords: Late-glacial, Younger Dryas, Salpausselkä moraines, Finland

Corresponding author email: joakim.donner@saunalahti.fi

Editorial handling: Joonas Virtasalo

\section{Introduction}

The pronounced transient period of climatic deterioration after the last glaciation, by Jessen (1935) pollen analytically defined in Denmark as the last late-glacial period, the Younger Dryas, was prece- ded by the Alleröd period and followed by the postglacial amelioration of climate at the beginning of the Holocene. The Alleröd and Younger Dryas periods were identified by the end of the 1940s in a 
number of sites in Denmark, southern Sweden and Norway, as well as elsewhere in northern continental Europe and in Britain. Summarizing these results, and taking into account the spatial distribution of the sites where Alleröd deposits had been identified, a correlation of the Younger Dryas with the formation of the Salpausselkä moraines in Finland was presented in a pollen-analytical study (Donner, 1951). The correlation had already been indicated in previous studies as the Salpausselkä moraines, being part of the Fennoscandian moraines, were formed during the last major standstills or re-advances of the ice margin before the final melting and withdrawal of the Scandinavian ice sheet (Fig. 1).

At the time of the above-mentioned correlation, Younger Dryas could not be directly dated. During the formation of the Salpauselkä moraines, the Baltic was an ice-dammed lake, the Baltic Ice Lake (BIL), which was drained at Billingen in Sweden at the time when the ice margin withdrew from the moraines. This event, recorded in the varved

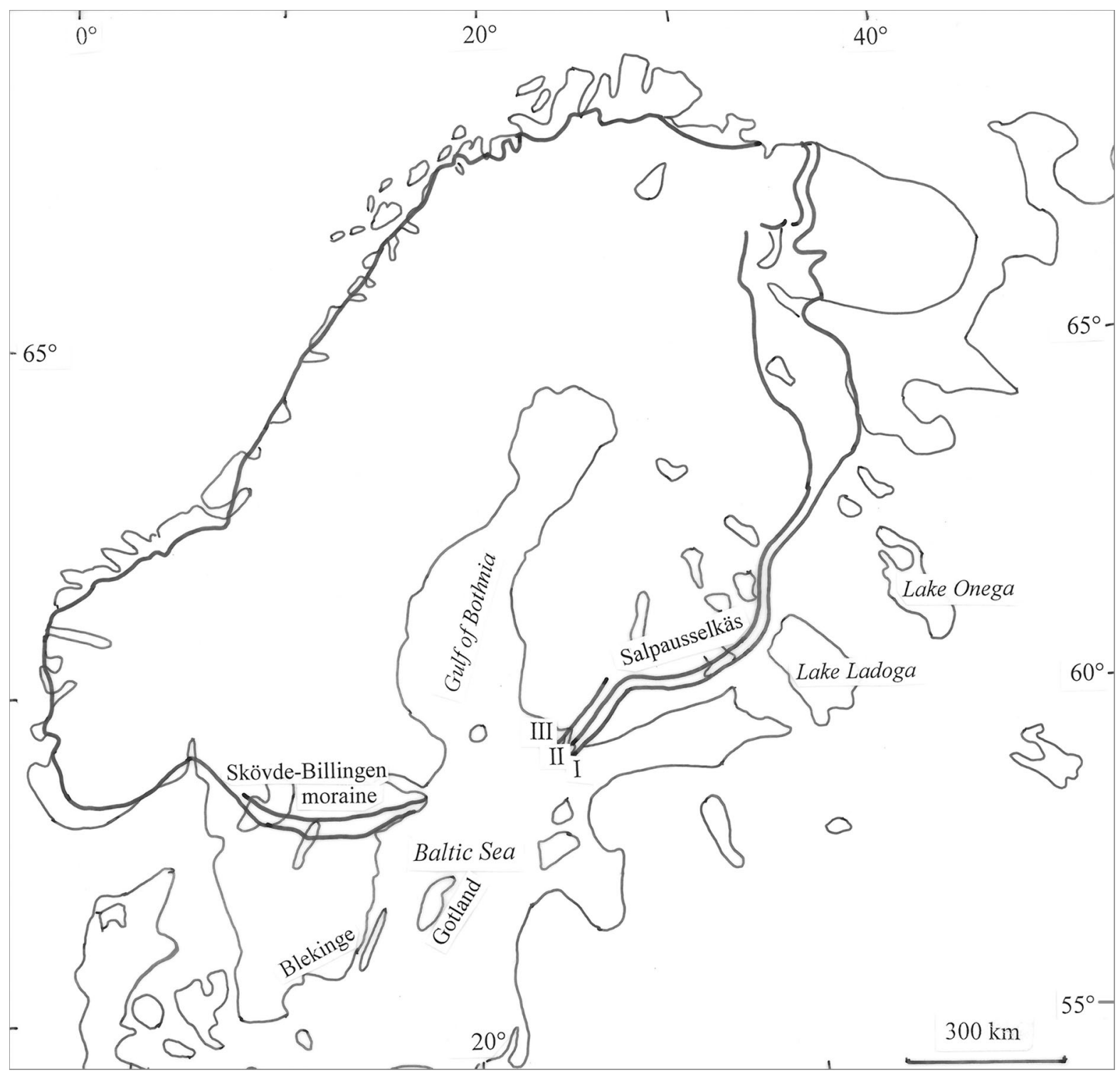

Fig. 1. The Salpausselkä moraines in Finland and the Skövde-Billingen moraines in Sweden in the Younger Dryas zone of the Fennoscandian moraines. 
clays as a drainage varve, was used indirectly to give an age for the climatic change at the end of the Younger Dryas. In Sweden, the drainage of the Baltic Ice Lake was dated by De Geer (1940) at 7912 BC, whereas in Finland it was dated by Sauramo (1940) at $7858 \mathrm{BC}$, thus at about $7900 \mathrm{BC}$ or $9850 \mathrm{BP}$. Later Sauramo (1949), however, concluded that there was an approximately 1000 year gap in the Swedish varve chronology and that the retreat of the ice margin from the Salpauselkä moranes therefore started at about $9000 \mathrm{BC}$, or $10950 \mathrm{BP}$, an age mentioned in the correlation of the moraines with Younger Dryas (Donner, 1951).

The correlation of Younger Dryas with the Salpausselkä moraines, and with the Fennoscandian moraines as a whole, is with some modifications still generally accepted after 60 years of detailed studies of the period; in Sweden, for instance, the Skövde and Billingen moraines (Fig. 1) have been referred to as representing the Younger Dryas ice-marginal zone (Lundqvist, 1995). As Younger Dryas is characterized by an exceptionally rapid cold reversal interrupting the general climatic amelioration after the last glaciation, it has been studied in great detail. With the improvement of dating methods it has been possible to date it accurately and to define its limits. The present contribution is presented in order to elucidate how much and to what extent the age of Younger Dryas has changed since it was correlated with the Salpausselkä moraines in Finland (Donner, 1951), and how accurately it can be compared with the formation of these moraines and the drainage of the Baltic Ice Lake. As the drainage marks the beginning of the withdrawal of the ice from the moraines, its age compared with the end of the Younger Dryas period gives an indication of how quickly the margin of the Scandinavian ice sheet reacted to the amelioration of climate after the Younger Dryas.

\section{Pollen stratigraphy and radiocarbon ages}

The biostratigraphical correlation based on pollen diagrams changed when the radiocarbon method became widely used. Using the average radiocar- bon ages from southern Scandinvia for the late-glacial pollen zones, a chronostratigraphic scheme was presented by Mangerud et al. (1974). The average of 15 ages for the upper boundary of Younger Dryas was $10099 \mathrm{yr}$. BP and of 8 ages for the lower boundary 10981 yr. BP, thus for a period of about 900 years. In the scheme, the boundaries were placed at 10000 and $11000{ }^{14} \mathrm{C}$ yr. BP. When the conventional radiocarbon ages are calibrated to calendar years, using the data from Reimer et al. (2004), the above-mentioned ages for Younger Dryas are 11480 and $12915 \mathrm{cal} .{ }^{14} \mathrm{C}$ yr. BP (Table 1).

When the first radiocarbon ages from sites in Finland became available it was clear that the basal organic sediments described as representing Younger Dryas (Donner, 1951) were all early Holocene in age. Later, however, a pollen assemblage zone, P.A.Z., with a maximum of non-tree pollen, NAP, and characterized by high percentages of Artemisia pollen, was identified in pollen diagrams from south-eastern Finland in the zone of the Salpausselkäs and their foreland (Hyvärinen, 1971, 1973). The conventional radiocarbon ages of the Artemisia zone in four studied profiles (Tolonen, 1967; Repo \& Tynni, 1967, 1969, 1971) were all within the limits of Younger Dryas (Table 1), with which the Artemisia zone was correlated in a summary of the stratigaphical division of the Finnish pollen diagrams (Donner, 1971). The youngest age of 10030 $\pm 160 \mathrm{BP}, 11540 \mathrm{cal} .{ }^{14} \mathrm{C}$ yr. BP, is close to the age of the upper boundary of the Younger Dryas chronozone as defined by Mangerud et al. (1974). Two of the above-mentioned sites, Mustalampi and Koivusilta, were later studied in greater detail with additional radiocarbon AMS ages, which, however, did not alter the conclusions about the age of Younger Dryas (Bondestam et al., 1994).

\section{Dating of the drainage of the Baltic Ice Lake}

The drainage of the Baltic Ice Lake by $27-28 \mathrm{~m}$ when the ice margin was at the second Salpausselkä can morphologically be traced on the basis of the distribution of the marginal deltas and sandur-deltas formed before and after the drop of water level 
Table 1. Ages of Younger Dryas and the drainage of the Baltic Ice Lake.

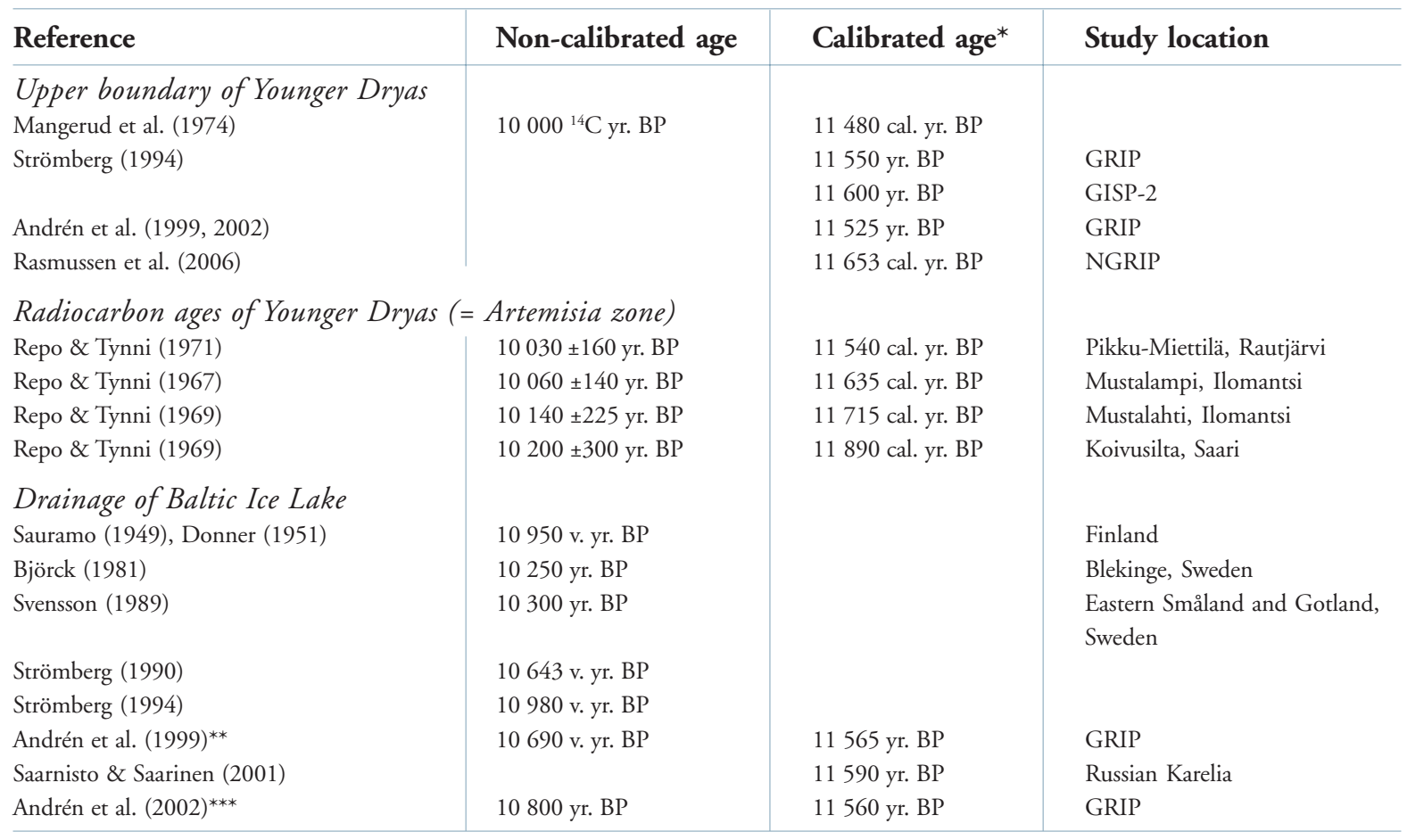

$\mathrm{BP}=$ before $1950 \mathrm{v}$. yr. $\mathrm{BP}=$ varve years before 1950

* Calibrated following Reimer et al. (2004)

** 875 varves missing

*** 760 varves missing

at the beginning of the Yoldia Sea stage in the Baltic. The scheme represented by Sauramo (1940) used in the pollen-analytical study by Donner (1951) was later simplified to a scheme with only one drainage of the Baltic Ice Lake (Donner, 1992), without any additional great water-level fluctuations during the formation of the Salpausselkä moraines.

The age of the drainage as traced in the varved clays is, as pointed out earlier, of particular interest in comparing the age of the Salpausselkä moraines with Younger Dryas. The two main moraines, Ss I and Ss II, were according to the Finnish varve chronology formed in 660 years (Sauramo, 1918, 1923, 1929), thus in a shorter time than that of the Younger Dryas period. During the retreat of the ice margin there was an additional standstill when the third Salpausselkä, Ss III, was formed, from which the retreat started 292 years after the drainage, which in the Finnish varve chronology represents the zero year.
The dating of the drainage of the Baltic Ice Lake with varved clays can in Finland only be done by connecting the Finnish chronology with the Swedish varve time scale across the Gulf of Bothnia. Thus, in the comparison of the Swedish and Finnish time scales Strömberg (1990) concluded that the zero year in Finland corresponed to the year 1405 in Sweden, dated at 8593 BC, 10643 BP (Table 1), a year used in a comparison of the two varve chronologies (Donner, 1995). Later, in discussing the varve dating of the deglaciation at $\mathrm{Mt}$. Billingen in Sweden, Strömberg (1994) correlated the beginning of the rapid ice recession from the main moraines, described by him as the MiddleSwedish moraines, with the change in climate after Younger Dryas, c. 10940 v. yr. BP in the Swedish time-scale. The final drainage of the Baltic Ice Lake was given an age of c. 10980 v. yr. BP.

By connecting the onset of the rapid retreat of the ice margin with the Younger Dryas / Preboreal 
(Holocene) boundary, which in the Greenland ice cores GRIP (Johnsen et al., 1992) and GISP-2 (Taylor et al., 1993) had been dated at c. 11550 and c. 11600 BP respectively, Strömberg (1994) concluded that the difference in age of 800-900 years as compared with the varve age for the beginning of the rapid ice retreat in Sweden could not conceivably have been caused by a time-lag in the retreat of the ice margin. The discrepancy between varve years and age determinations of Younger Dryas was in later investigations taken to be caused by an error in the Swedish varve chronology, suggesting a large gap of missing years in the varve sequence.

In two cores of varved clay from the Baltic southeast of Stockholm, Andrén et al. (1999) were able to link the Swedish varve chronology with the local pollen assemblage zones in the cores, and further with the Younger Dryas / Preboreal boundary of the regional pollen stratigraphy. The age obtained for the boundary was c. $10650 \mathrm{v}$. yr. BP, which was then compared with the age in the Greenland ice core, GRIP, of $11525 \mathrm{yr}$. BP This led to the conclusion that the difference between the two ages meant that c. 875 years were missing in the varve time-scale for varves younger than 10300 years. As the Younger Dryas / Preboreal boundary in the varved clays coincided with the onset of the rapid rate of ice recession, the results showed that there was no time-lag in the response of the ice margin to the change in climate, in agreement with Strömberg's conclusion. In the Swedish varve chronology the drainage of BIL took place c. 40 years prior to the above-mentioned boundary, thus at c. 11565 yr. BP The age for the beginning of the rapid ice recession, as quoted above, showed some local variations in Sweden, as pointed out by Andrén et al. (1999), and the ages must therefore be taken as approximate ages.

In a study of cores of varved sediments from Lake Onega in Russian Karelia, the longest one with 1300 varves, Saarnisto \& Saarinen (2001) identified a westerly palaeomagnetic declination peak with a calibrated AMS radiocarbon age of $13090 \mathrm{yr}$. BP. The same peak was traced in an earlier studied section of varved clays with 1700 varves in Helylä in the outskirts of Sortavala on the northern shore of
Lake Ladoga. After the declination peak, 1500 varves were formed until the deposition ceased as a result of the drainage of the Baltic Ice Lake. By subtracting 1500 years from the calibrated AMS age of $13090 \mathrm{yr}$. BP for the palaeomagnetic declination peak the age of $11590 \mathrm{yr}$. BP was obtained for the drainage (Table 1).

In the study of the varved clays in cores from the Baltic Sea (Andrén et al., 1999) nine graphs were used for cross-correlating. Later, five new varve graphs were added, covering the period of c. 11530 to 10250 v. yr. BP (Andrén et al., 2002). The varve age of the drainage of the Baltic Ice Lake was dated at $10800 \mathrm{v}$. yr. BP, close to a colour change in the clays and also to the somewhat younger Younger Dryas / Preboreal transition. By using the calendar years BP in the GRIP Event Stratigraphy, with its $\mathrm{d}^{18} \mathrm{O}$ record, the drainage was dated at $11560 \mathrm{yr}$. BP and the Younger Dryas / Preboreal boundary at 11525 yr. BP. The missing years in the Swedish time scale were according to the correlation c. 760 years in the part of the scale younger than c. 10300 v. yr. BP.

The age of $11560 \mathrm{cal}$. yr. BP for the drainage of the Baltic Ice Lake to the level of the Yoldia Sea was again used in the study by Andrén et al. (2007) of a sediment core from the Blekinge archipelago in southern Sweden. On the basis of earlier studies on the pollen stratigraphy of sediments of lakes and mires in Blekinge, detailed shoreline displacement curves had been constructed, in which the dating of the final drainage of the Baltic Ice Lake was based on radiocarbon ages and compared with pollen zones (Berglund, 1966; Björck, 1981). It was thus an area in which the shoreline displacement could directly be dated using ages of the isolation levels of basins below the highest shoreline. Björck (1981) dated the lowering of the Baltic Ice Lake from $30 \mathrm{~m}$ a.s.l. to at least $4 \mathrm{~m}$ a.s.l. at 10250 radiocarbon years BP, an age somewhat younger than those listed in Table 1.

In a detailed study of basins and raised beaches on the island of Gotland and in eastern Småland on the mainland, Svensson (1989) demonstrated that the initial drainage of the Baltic Ice Lake by 25 $\mathrm{m}$ was a rapid regression, dated at c. 10300 radio- 
carbon years BP, in agreement with the age determined by Björck (1981) in Blekinge (Table 1). Svensson also presented a map of the isobases of the Baltic Ice Lake prior to the final drainage, in Finland including the area north of Salpausselkä II. In addition, a detailed digital 3 D-reconstruction of the Baltic Ice Lake, before its drainage, was presented by Jakobsson et al. (2007).

The dating of the drainage of the Baltic Ice Lake based on radiocarbon ages of sediments of lakes and mires presented by Björck (1981) and Svensson (1989) are, as seen in Table 1, somewhat younger than those based on varved clays in later studies making comparisons with ages of the Younger Dryas in Greenland ice cores.

\section{Conclusions}

In the numerous studies of Younger Dryas, and the Late-glacial in general, it soon became clear that the boundaries as defined in southern Scandinavia (Mangerud et al., 1974) are diachronous in a wider area (Hoek, 2008). In many biostratigraphical studies of Younger Dryas, the radiocarbon ages have been quoted as calibrated ages BP as given by Reimer et al. (2004), in addition to conventional ages, but in studies of varved clays comparisons have been made with the oxygen isotope stratigraphy in the Greenland ice cores, both with GRIP (Johnsen et al., 1992) and with GISP-2 (Taylor et al., 1993). In this way, years missing in the varve chronology could be demonstrated in the Swedish time scale, by Andrén et al. (2002) concluded as being 760 years.

In order to define the Late-glacial stadials and interstadials, an Event Stratigraphy based on the Greenland ice-core record from NorthGRIP (NGRIP) was presented as a standard scheme for the North Atlantic region (Rasmussen et al., 2006; Hoek, 2008). The age of the upper boundary of GS-1 (= Younger Dryas) in the Event Stratigraphy, 11653 cal. yr. BP, and the formally ratified age of 11650 yr. BP for the base of the Holocene, are close to the ages obtained for this boundary listed in Table 1, and also to the ages for the drainage of the Baltic Ice Lake. This means that as a result of the climate change about 11600 years ago, the ra- pid retreat of the ice margin in Finland and Sweden began so soon that a delay cannot with certainty be demonstrated. On the other hand, the response of the ice margin during the cold Younger Dryas is complex. According to the Finnish varve chronology the two main Salpausselkä morains, Ss I and Ss II, were formed in 660 years. If the drainage of the Baltic Ice Lake north of Salpausselkä II is dated at 11600 yr. BP, and if the varve chronology is correct, the two Salpauselkäs were formed between about 12260 and 11600 yr. BP, in a shorter time than the length of the Younger Dryas of nearly 1200 years in the Event Stratigraphy based on NGRIP. This means that the first Salpausselkä was formed during a standstill, or after a re-advance, of the ice margin nearly 600 years after the pronounced beginning of the Younger Dryas. The reaction of the margin of the retreating Scandinavian inland ice may thus have been delayed in the beginning of the pronounced Younger Dryas deterioration of climate, but not during the amelioration of climate at the beginning of the Holocene. The formation of Ss I would, according to the varve chronology presented by Niemelä (1971), have started already 1124 years before the drainage of the Baltic Ice Lake, i.e. the end of Younger Dryas. The above-mentioned period of 660 years for the formation of the Salpausselkäs agrees, however, with the length of 600-700 years for the formation of the two corresponding moraines of Skövde and Billingen in central Sweden (Strömberg, 1989, 1990; Lundqvist, 1995) and is therefore considered to be more reliable.

That two major moraines, Ss I and Ss II, separated by a zone of withdrawal, were formed in Finland during the Younger Dryas suggests that there were fluctuations of climate during this period. The less conspicuous Salpausselkä III moraine in Southwestern Finland was, according to the Finnish varve chronology, formed about 300 years after the beginning of the Holocene.

The chronological relationship between Younger Dryas, as defined in the Event Stratigraphy, and the Salpausselkä moraines in Finland can, on the basis of the studies quoted above, be summarized as in Figure 2. The difference between the correlation given above to that presented sixty years ago 
Holocene Salpausselkä III

— 11653 yr. BP Drainage of the Baltic Ice Lake at $\sim 11600$ yr. BP

Younger Salpausselkä II

Dryas Salpausselkä I from 12 260 yr. BP

-12846 yr. BP

Fig. 2. Chronological relationships between Younger Dryas and the Salpausselkä moraines.

(Donner, 1951) is in the older age of Younger Dryas and in Salpausselkä III not being included in Younger Dryas. There have, however, been changes in the age of the Younger Dryas over the years, based on the Greenland ice cores, as the methods of dating have been refined. The Event Stratigraphy is based on NGRIP, whereas earlier comparisons were made with GRIP and GISP-2. The small differences in the interpretations of the chronology have also been due to how Younger Dryas has been defined.

In addition to the dating of the Salpausselkä moraines in Finland using varve years and radiocarbon ages, surface exposure dating with cosmogenic nuclides has been applied. ${ }^{10} \mathrm{Be}$ dating of boulders on Salpausselkä I west of Lahti in southern Finland gave a mean exposure age of $11420 \pm 470 \mathrm{yr}$., which taking into account the erosion of rock surfaces increases the age to $11610 \pm 470 \mathrm{yr}$. (Tschudi et al., 2000). It was considered to be within the range of Younger Dryas in the GRIP and GISP-2 ice cores and the varve dating of Ss I by Niemelä (1971). As the age is close to the age for the drainage of the Baltic Ice Lake and the end of the Younger Dryas, when Ss II was formed, the age of the surface exposure dating of the boulders on Ss I is several hundred years too young, even if the margin of error is taken into account. The general usefulness of exposure dating of glacial landforms has, however, been demonstrated in many areas (Reuther et. al., 2006).

No conclusive explanation has yet been found for why there was a rapid cooling in the beginning of the Younger Dryas event recorded in the isotope record from Greenland.

\section{Acknowledgements}

The author is grateful for the constructive comments on the manuscript by Thomas Andrén and Matti Saarnisto.

\section{References}

Andrén, T., Björck, J \& Johnsen, S. 1999. Correlation of Swedish glacial varves with the Greenland (GRIP) oxygen isotope record. Journal of Quaternary Science 14, 361-371.

Andrén, T., Lindberg, G. \& Andrén, E. 2002. Evidence of the final draiage of the Baltic Ice Lake and the brackish phase of the Yoldia Sea in glacial varves from the Baltic Sea. Boreas 31, 226-238.

Andrén, T., Andrén, E., Berglund, B.E. \& Yu, S.-Y. 2007. New insights on the Yoldia Sea low stand in the Blekinge archipelago, southern Baltic Sea. GFF 129, 277-285.

Berglund, B.E. 1966. Late-Quaternary vegetation in eastern Blekinge, southeastern Sweden: A pollen-analytical study. I. Late-glacial time. Opera Botanica 12, 1-180.

Björck, S. 1981. A stragraphic study of Late Weichselian deglaciation, shore displacement and vegetation history in south-eastern Sweden. Fossils and Strata 14, 1-93.

Bondestam, K., Vasari, A., Vasari., Y., Lemdahl, G. \& Eskonen, K. 1994. Younger Dryas and Preboreal in Salpausselkä foreland, Finnish Karelia. In: Lotter, A.F. \& Amman, B. (eds.) Festschrift Gerhard Lang. Dissertationes Botanicae 234, 161-206.

Donner, J. 1951. Pollen-analytical studies of late-glacial deposits in Finland. Comptes Rendus de la Société géologique de Finlande 24, 1-92.

Donner, J. 1971. Towards a stratigraphical division of the Finnish Quaternary. Societas Scientiarum Fennica, Commentationes Physico-Mathematicae 41, 281-305.

Donner, J. 1992. Is there evidence in the zone of the first Salpausselkä moraine in Finland of a transgression before the drainage? Sveriges Geologiska Undersökning Ca 81, 8790.

Donner, J. 1995. The Quaternary history of Scandinavia. Cambridge University Press, 200 pp. 
Hoek, W.Z. 2008. The Last Glacial-Interglacial Transition. Episodes 31, 226-229.

Hyvärinen, H. 1971. Two Late Weichselian stratigraphical sites from the foreland of the Salpausselkäs in Finland. Societas Scientiarum Fennica, Commentationes Biologicae 40, 1-12.

Hyvärinen, H. 1973. The deglaciation history of eastern Fennoscandia - recent data from Finland. Boreas 2, 85-102.

Jakobsson, M., Björck, S., Alm, G., Andrén, T., Lindeberg, G. \& Svensson, N. 2007. Reconstructing the Younger Dryas ice dammed lake in the Baltic Basin: Bathymetry, area and volume. Global and Planetary Change 57, 355-370.

Johnsen, S. J., Clausen, H. B., Dansgaard, W., Fuhrer, K., Gundestrup, C. U., Hammer, C. U., Iversen, P., Jonzel, J., Stauffer, B. \& Steffansen, J. P. 1992. Irregular glacial interstadials recorded in a new Greenland ice core. Nature 359, 311-313.

Lundqvist, J. 1995. The Younger Dryas icemarginal zone in Sweden. Quaternary International 28, 171-176.

Mangerud, J., Andersen, S. T., Berglund, B. E. \& Donner, J. J. 1974. Quaternary stratigraphy of Norden, a proposal for terminology and classification. Boreas 3, 109-128.

Niemelä, J. 1971. Die quartäre Stratigraphie von Tonablagerungen und der Rückzug des Inlandeises zwischen Helsinki und Hämeenlinna in Südfinnland. Geological Survey of Finland, Bulletin 253, 1-79.

Rasmussen, S. O., Andersen, K. K., Svensson, A. M., Steffensen, J. P., Vinther, B. Clausen, H. B., Siggaard-Andersen, M. L., Johnsen, S. J., Larsen, L. B., Dahl-Jensen, D., Bigler, M., Röthlisberger, R., Fischer, H., Goto-Azuma, K., Hansson, M. \& Ruth, U. 2006. A new Greenland ice core chronology for the last glacial termination. Journal of Geophysical Research 111, D06102.

Reimer, P. J., Baille, M. G. I., Bard, E., Bayliss, A., Warren, B. J., Chanda, B. J. H., Blackwell, P. G., Buck, C. E., Burr, G. S., Cutler, K. B., Damon, P. E., Edwards, R. L., Fairbanks, R. G., Friedrich, M., Guilderson, T. P., Hogg,A. G., Hughen, K. A., Kromer, B., McCormac, G., Manning, S., Ramsey, C. B., Reimer, R. W., Remmele, S., Southon, J. R., Stuiver, M., Talamo, S., Taylor, F. W., van der Plicht, J. \& Weyhenmeyer, C. E. 2004. IntCal104 terrestrial radiocarbon age calibration, 0-26 cal kyr BP. Radiocarbon 46, 1029-1058.

Repo, R. \& Tynni, R. 1967. Zur spät- und postglazialen Entwicklung im Ostteil des ersten Salpausselkä. Comptes Rendus de la Société géologique de Finlande 39, 133159.

Repo, R. \& Tynni, R. 1969. Morphologisch-stratigraphische Grundzüge des östlichen Salpausselkä gebiets. Bulletin of the Geological Society of Finland 41, 203-229.

Repo, R. \& Tynni, R. 1971. Observations on the Quaternary geology of an area between the $2^{\text {nd }}$ Salpausselkä and the ice-marginal formation of Central Finland. Bulletin of the Geologica Society of Finland 43, 185-202.
Reuther, A.U., Ivy-Ochs, S. \& Heine, K. 2006. Application of surface exposure dating in glacial geomorphology and the interpretation of moraine ages. Zeitschrift für Geomorphologie, Supplement 142, 335-359.

Saarnisto M. \& Saarinen, T. 2001. Deglaciation chronology of the Scandinavian Ice Sheet from the Lake Onega Basin to the Salpausselkä End Moraines. Global and Planetary Change 31, 387-405.

Sauramo, M. 1918. Geochronologische Studien über die spätglaciale Zeit in Südfinnland. Fennia 41, 1-44.

Sauramo, M. 1923. Studies on the Quaternary varve sediments in southern Finland. Bulletin de la Commission géologique de Finlande 60, 1-144.

Sauramo, M. 1940. Suomen luonnon kehitys jääkaudesta nykyaikaan. Werner Söderström, Porvoo, 286 pp.

Sauramo, M. 1929. The Quaternary geology of Finland. Bulletin de la Commission géologique de Finlande 86, 1110.

Sauramo, M. 1949. Das dritte Scharnier der fennoscandischen Landhebung. Societas Scientiarum Fennica, Årsbok-Vuosikirja 27, 1-26.

Strömberg, B. 1990. A connection between the clay varve chronologies in Sweden and Finland. Annales Academiae Scientiarum Fenncae A III 154, 1-32.

Strömberg, B. 1994. Younger Dryas deglaciation at Mt. Billingen, and clay varve dating of the Younger Dryas / Preboreal transition. Boreas 23, 177-193.

Svensson, N.-O. 1989. Late Weichselian and Early Holocene shore displacement in the central Baltic, based on stratigraphical and morphological records from eastern Småland and Gotland, Sweden. University of Lund, Department of Quaternary Geology, Thesis 25, 1-195.

Taylor, K.C., Hammer, C.U., Alley, R.B., Clausen, H.B., DahlJensen, D., Cow, A.J., Gundestrup, N.S., Kipfstuhl, J., Moore, J.C. \& Waddington, E.D. 1993. Electrical conductivity measurements from the GISP2 and GRIP Greenland ice cores. Nature 366, 549-552.

Tschudi, S., Ivy-Ochs, S., Schüchter, C., Kubik, P. \& Rainio, H. 2000. ${ }^{10} \mathrm{Be}$ dating of Younger Dryas Salpausselkä I formation in Finland. Boreas 29, 287-293.

Tolonen, K. 1967. Über die Entwicklung der Moore im finnischen Nordkarelien. Annales Botanici Fennici 4, 219-416.

Walker, M., Johnsen, S., Rasmussen, S. O., Popp, T., Steffensen, J.-P., Gibbard, P., Hoek., W., Lowe, J., Andrews, J., Björck, S., Cwynar, L. C., Hughen, K., Kershaw, P., Kromer, B., Litt., T., Lowe, D. J., Nakagawa, T., Newnham, R. \& Schwander, J. 2009. Formal definition and dating of the GSSP (Global Stratotype Section and Point) for the base of the Holocene using the Greenland NGRIP ice core, and selected auxiliary records. Journal of Quaternary Science $24,3-17$. 